Relations industrielles

Industrial Relations

\title{
The Canadian Industrial Strategy
}

\section{Arthur W. Donner et Fred Lazar}

Volume 30, numéro 4, 1975

URI : https://id.erudit.org/iderudit/028665ar

DOI : https://doi.org/10.7202/028665ar

Aller au sommaire du numéro

\section{Éditeur(s)}

Département des relations industrielles de l'Université Laval

\section{ISSN}

0034-379X (imprimé)

1703-8138 (numérique)

Découvrir la revue

\section{Citer cet article}

Donner, A. W. \& Lazar, F. (1975). The Canadian Industrial Strategy. Relations industrielles / Industrial Relations, 30(4), 775-781.

https://doi.org/10.7202/028665ar

Tous droits réservés @ Département des relations industrielles de l'Université Laval, 1975
Ce document est protégé par la loi sur le droit d'auteur. L'utilisation des services d'Érudit (y compris la reproduction) est assujettie à sa politique d'utilisation que vous pouvez consulter en ligne.

https://apropos.erudit.org/fr/usagers/politique-dutilisation/ 
the process of moving from one point to another. It can give us no information, therefore, about the speed of the change. ${ }^{9}$

Alternatively, consider the process of mechanising a particular industry. Every year, new machines are introduced into the said industry. Now suppose that the process of mechanisation is speeded up; clearly there will come a time when those disemployed from the one industry will not suffice for the needs of the machine making industry, and there will be a shortage of labour.

\section{THE CANADIAN INDUSTRIAL STRATEGY}

\section{A COMMENT}

\section{Arthur W. Donner \\ and}

Fred Lazar

\section{A FRAMEWORK FOR INDUSTRIAL POLICY MAKING}

The concept of an industrial strategy for Canada suggests a set of deliberate long-run policies aimed at affecting the fundamental structure of Canadian industry. It tends to emphasize deliberate and active government involvement.

In actual fact, the changes which do take place in the structure of our economy seldom stem from government actions aimed at achieving such long-term objectives. Important changes often evolve gradually, in an incremental and adaptive fashion, in response to particular shortterm objectives. The difficulty with this gradual process is that the longrun changes which may be traced to government action often take place primarily as residual side effects of individual short-term measures. What is more, the short-term government objectives themselves are often crisis oriented, originating with the need for immediate action to remedy particular problems.

9 It is interesting that the report of the U. S. National Commission on Technology, Automation, and Economic Progress, Technology and the American Economy (1966) starts on this theme. Chapter one bears the title: "The Pace of Technological Change, » and yet the analysis of the report throws no light on the matter, being limited to the long run analytical approach, and not considering any investment which would normally be associated with it, increasing in volume when the pace increases. 
Under such conditions, the long-run implications of piecemeal policy decisions oriented to individual crises may lead policy makers to positions they might never have wished to adopt had they considered the matter from a long-run perspective. With clearly defined long-run objectives at the outset, such developments could be averted.

Many policy considerations have long-term implications, whether directly recognized or not. They include such routine short-term matters as stabilization policies aimed at affecting unemployment, inflation or the balance of payments. They also include less frequently altered aspects of the legislated economy, such as monetary and fiscal policy as well as the tax structure, the tariff system, the regulation of competition, income redistribution programmes, regional incentives, restrictions on foreign ownership in key sectors - all of which define the framework in which Canadian economic activity is organized.

The crucial aspects of industrial strategy thus becomes the need to establish and recognize desired long-term industrial goals. In so doing, this will promote the identification of all long-term policy implications whether derived from fundamental tax changes or from short-term stablization programmes. Furthermore, it will provide guideposts for evaluating the desirability of any policies in terms of their long-run implications. In other words, it will facilitate adoption of long range strategic planning on a wider scale, helping to replace many of the ad hoc approaches currently in use.

Advocates of strategic planning are becoming more vocal, and it has now become fashionable to talk of an «industrial strategy ; a new national plan to replace Sir John A. MacDonald's National Policy of tariffs, railways, immigration and land settlement. For instance, some argue that the complete removal of the tariff and other barriers to the movement of capital and labour between Canada and the U.S. would be to the country's long-run advantage. (This is the «continentalist» strategy). Others argue for the strict limitation of foreign ownership and/or control of Canadian industry and strong government-supported industrial development. In fact, there exists a whole spectrum of policy options.

The new found enthusiasm for an industrial strategy is also imbued with impatience. Immediate action is desired. There is no time for serious reflection upon the current situation. Yet this had been the main pitfall of past and present government action. Standing back to undertake a careful assessment of one's current position and then designing a path to be followed are the keys to the implimentation of a successful national plan.

* A.W. DONNER, Donner and Lazar Research Associates, To:onto, Ontario.

* F. LAZAR, York University and Donner \& Lazar Research Associates. 
One of the important building blocks in the development of national priorities should be an assessment of where the manufacturing sector fits into such a schema.

\section{HOW IMPORTANT IS MANUFACTURING ?}

An economic orthodoxy has emerged which emphasizes the key role of the manufacturing sector in the three principal industrial layers of our economy, the so-called primary, secondary and tertiary sectors. The principles underlying this view have never been rigorously established, and their ambiguous nature have possibly resulted in a misunderstanding of the importance of industrial linkages. It follows that assigning a major role to the Canadian manufacturing sector in long-term economic planning may be based on a series of questionable assumptions concerning economic linkages and national priorities.

The historical antecedents of this view date back, at the very least, to the early eighteenth century, when Physiocrats like Quesnay argued that only agriculture produced true value. Other forms of employment yielded no additions to income. Economic growth was related directly to the surplus generated in the agriculture sector which accrued to the landlords. At a time when over 90 per cent of the population were involved in agriculture, such propositions seemed reasonable.

The Industrial Revolution with its factory system and mass markets shifted the attention of the nineteenth century classical economists to other industries, particularly the manufacturing sector and the resource industries supporting the industrial superstructure, such as mining and agriculture. Once again, it was assumed that the surplus generated in these sectors supported the growth in other sectors. This view has persisted to this day with some minor modifications.

Current economic development literature tends to be vague, but a consistent thread running through many of the influential pieces emphasizes the need to establish and fortify those manufacturing industries which demonstrate strong backward and forward linkages to other sectors. Ironically, the development strategies of socialist and capitalist planners typically converge to the view that manufacturing represents a key sector of the economy.

In Canada, the policy emphasis on manufacturing has several origins - in part stemming from influential studies on the structure of industry in the U.S. The arguments are usually ambiguous, sometimes stressing the so-called 'central' role of the manufacturing group as a conduit between the resource sectors and the final consumers. The following list simply attempts to tie together in a brief fashion some of the points usually used in defence of this conventional view. 
SIZE

In Canada manufacturing is important simply on the basis of size. The Canadian manufacturing industries account for $26 \%$ of output and employ about $23 \%$ of all workers.

\section{CAPITAL INTENSITY}

Manufacturing accounted for about one-quarter of private business capital formation in 1971 and 1972.

\section{SCALE EFFects}

The Canadian manufacturing group is composed of relatively large firms, which tend to operate in an oligopolistic protected domestic rnarket.

INDUSTRIAL INTERDEPENDENCE

In a static sense, the manufacturing group of industries appear to have strong backward and forward linkages. A backward link can be measured by the proportion of output due to purchases from supplying industries. A forward linkage can be measured by the proportion of output going to sectors other than final consumer demand.

\section{INFLATION POTENTIAL}

Because of its generally high levels of productivity, the manufacturing industries tend to be laggers in the inflation race. For example, between 1961 and 1970, the manufacturing selling price index rose at an annual rate of $1.8 \%$ compared with a rate of $2.3 \%$ in the consumer price index.

\section{INDUSTRIAL GROWTH RACE}

As already indicated, since 1960 manufacturing has been one of the leading growth sectors of the economy - although certain service industries have grown as rapidly or even more rapidly.

\section{TECHNOLOGICAL INNOVATION}

The U.S. literature has emphasized the concentration of the research and development effort in the manufacturing group - particularly aircrafts and missiles, electrical equipment, communications equipment, machinery, chemical, etc.

\section{Key Wage Bargains}

In the U.S., the key wage bargains appear to originate in steel, auto, metalworking, fabricating, and cement. These pace setting agreements are all in the manufacturing sector.

\section{Full EMPloyment BotTlenecks}

Both in the mid 1950's and mid 1960's the full employment bottlenecks appeared serious only when the manufacturing group began to operate at or near capacity. 
The Politics of International Trade in Manufactured Commodities

The Canadian manufacturing sector is intergrated with the U.S. market through a complex series of arrangements and special trade pacts. In 1972 exports of finished commodities to the U.S. (primarily manufactured goods) amounted to nearly $\$ 6.8$ billion of which autos made up $\$ 4.5$ billion. The U.S. purchased $86 \%$ of finished good exports in 1972 and $96 \%$ of our auto exports. In 1972, Canada registered a $\$ 2.7$ billion deficit in the two-way trade of finished goods with the U.S. The trade deficit was $\$ 3$ billion when autos are excluded.

Supporters of the thesis that manufacturing plays a critical role often cite evidence derived from input-output studies. Static input-outpout analysis tends to demonstrate the expected strong backward linkages between manufacturing industries and the following service industries : transportation, storage, communications; finance and insurance and business services; as well as forward linkages with the trade sector. Schematically, the linkages between manufacturing and the service industries can be illustrated in the following manner :

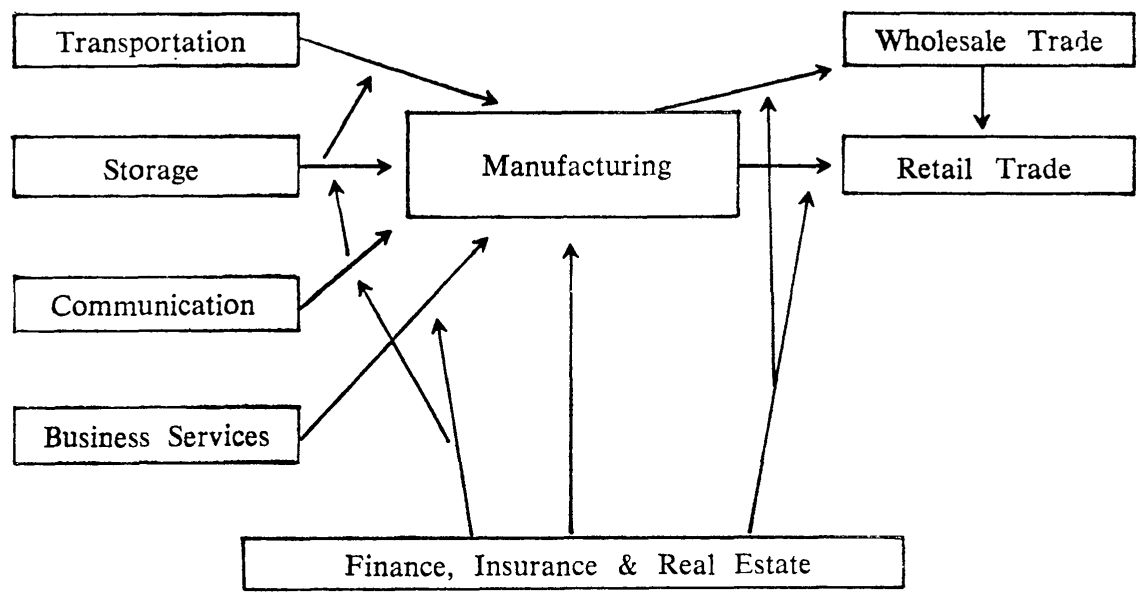

As may be seen from the above diagram, the manufacturing sector is situated in the middle, the activities of the service industries revolving around or spinning off this sector.

However, even a causal look at the service industry categories reveal the fragility of this type of analysis. Indeed, it becomes immediately apparent that the sales of a large segment of the service sector are not dependent to a significant extent on the secondary sector; for example, public administration, community and personal services, intercity bus, urban and airline transportation, and the radio and TV component of 


\section{TABLE 1}

\section{Service Industries Conceptually Independent of the Manufacturing Sector}

Industry

1961 RDF weight

Air Transport and Services Incidental to Air Transport (50 per cent) 10.2312

Bus Transport, Interurban and Rural

0.096

Urban Transit Systems

0.303

Radio and TV Broadcasting

0.255

Telephone Systems (50 per cent) 1

Post Office ( 50 per cent) 1

Wholesale Merchants excluding Construction Materials

and Supplies; Farm Machinery; Industrial and

Transportation Equipment and Supplies; Commercial,

Institutional and Service Equipment and Supplies (50 per cent) 1 ;

Newsprint, Paper and Paper Product (30 per cent) ${ }^{1}$

Retail Trade

Finance, Insurance and Real Estate (50 per cent) 1

Education and Related Services

Health and Welfare Services

Motion Picture and Recreational Services

Personal Services

Services to Business Management (50 per cent) 1

Public Administration and Defence

durables, are dependent for their sales on the activities of the above service industries ; the causation is by no means only one way determined.

An intuitive examination of the various service industry functions will show that almost 70 per cent of the so-called tertiary sector could operate in the absence of a domestic manufacturing sector. That is, the per cent of the service sector, yet they have no apparent input link with domestic manufacturing. In fact, certain manufacturing industries, notably sales of their services do not serve as important inputs into manufacturing. communication. * These industrial groups together make up about 36

* Inputs from the manufacturing sector may be important for several of these sectors. Yet manufacturing production abroad could quite easily fill domestic service needs. Indeed it is a simpler task for the government to stimulate manufacturing imports than to promote service exports.

1 Arbitrarily chosen

250 per cent of actual 1961 weight 
Of course these speculations assume that Canadian standards of living would be unaltered if Canada had a smaller manufacturing sector and a larger service or resource sector. Table I lists the industries. Prominent among these industries are retail trade and the consumer oriented wholesale merchants. A complete elimination of the domestic manufacturing industries group could conceivably result in an even larger wholesale and retail trade sector. This could follow from the spinning-off of some internal trade functions currently being undertaken by domestic manufacturing firms which would not be picked up by foreign manufacturing firms. This re-organization of industry is admittedly an unlikely proposition, but the example does illustrate the conceptual independence of these large sectors contrary to the basic implications derived from inputoutput analysis.

The trade sector behaves as an intermediary between manufacturers and consumers. Correspondingly, the growth of this sector is related to the increase in consumer spending and to that cost-reducing advantages of specialization. Part of the finance, insurance and real estate and business services industries are also included among these industries since their activities are tied to all forms of business, not just those that happen to be manufacturing concerns. Thus, the real importance of the Canadian manufacturing sector to the development of the service sector appears to be less than that suggested by input-output analysis alone. In essence, this is one of the issues that should be carefully explored before the outline of a national plan may be truly formulated.

\section{L'AMÉNAGEMENT DES TEMPS DE TRAVAIL}

\section{L'horaire variable et la semaine comprimée}

Introduction, Jean BOIVIN et Jean SEXTON - Les formes d'aménagement des temps de travail. Laurent BELANGER - L'horaire variable : anarchie ou désordre organisé, Marie-Claire BOUCHER - L'horaire variable : quelques conséquences, Jean-Pierre HOGUE - L'horaire variable : quelques expériences vécues, Gérard LEDUC, Jean-Claude BEAULIEU - La semaine comprimée de travail : progrès ou anachronisme, Bernard TESSIER - Les horaires comprimés et l'adaptation du travail à l'homme, Florian OUELLET - La semaine comprimée : quelques expériences vécues, Paul DEAMEN, Jean MERRILL - Réactions gouvernementales et syndicales, Jean BEAUDRY, Jean-Louis HARGUINDEGUY, Réal MIREAULT, L.-P. LEVAC Prendre le temps de vivre..., Jacques DE CHALENDAR - Bibliographie Annexe A: Terminologie et technique de l'horaire variable - Annexe B : L'enregistrement du temps par la méthode du totalisateur - Annexe C: Mémoire du Congrès du travail du Canada à la Commission d'enquête sur la modification ou la compression de la semaine de travail, 26 septembre 1972 , Ottawa.

1 volume, 337 pages - Prix : $\$ 7.00$

LES PRESSES DE L'UNIVERSITÉ LAVAL 